\title{
Capacitive electrical stimulation of a conducting polymeric thin film induces human mesenchymal stem cell osteogenesis
}

DOI:

10.1116/6.0001435

\section{Document Version}

Final published version

Link to publication record in Manchester Research Explorer

Citation for published version (APA):

Silva, R. A. D., Xue, R., Torresi, S. I. C. D., \& Cartmell, S. (2022). Capacitive electrical stimulation of a conducting polymeric thin film induces human mesenchymal stem cell osteogenesis. Biointerphases, 17(1), [11001]. https://doi.org/10.1116/6.0001435

\section{Published in:}

Biointerphases

\section{Citing this paper}

Please note that where the full-text provided on Manchester Research Explorer is the Author Accepted Manuscript or Proof version this may differ from the final Published version. If citing, it is advised that you check and use the publisher's definitive version.

\section{General rights}

Copyright and moral rights for the publications made accessible in the Research Explorer are retained by the authors and/or other copyright owners and it is a condition of accessing publications that users recognise and abide by the legal requirements associated with these rights.

\section{Takedown policy}

If you believe that this document breaches copyright please refer to the University of Manchester's Takedown Procedures [http://man.ac.uk/04Y6Bo] or contact uml.scholarlycommunications@manchester.ac.uk providing relevant details, so we can investigate your claim.

\section{OPEN ACCESS}




\section{Capacitive electrical stimulation of a conducting polymeric thin film induces human mesenchymal stem cell osteogenesis}

Cite as: Biointerphases 17, 011001 (2022); https://doi.org/10.1116/6.0001435

Submitted: 07 September 2021 - Accepted: 09 December 2021 • Published Online: 03 January 2022

(iD) Rubens Araujo da Silva, (D) Ruikang Xue, (D) Susana Inés Córdoba de Torresi, et al.

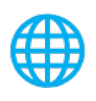

\section{AVS Quantum Science Now Publishing Original Research}




\title{
Capacitive electrical stimulation of a conducting polymeric thin film induces human mesenchymal stem cell osteogenesis
}

\author{
Cite as: Biointerphases 17, 011001 (2022); doi: $10.1116 / 6.0001435$ \\ Submitted: 7 September 2021 · Accepted: 9 December 2021 . \\ Published Online: 3 January 2022
}

Rubens Araujo da Silva, ${ }^{1}$ (D) Ruikang Xue, ${ }^{2}$ (D) Susana Inés Córdoba de Torresi, ${ }^{1, a)}$ (iD and Sarah Cartmell ${ }^{2}$ (iD

\begin{abstract}
AFFILIATIONS
1Departamento de Química Fundamental, Instituto de Química, Universidade de São Paulo, Av. Prof. Lineu Prestes, 748, CP 26077, 05508-000 São Paulo, Brazil

${ }^{2}$ Department of Materials, School of Natural Sciences, Faculty of Science and Engineering and The Henry Royce Institute, Royce Hub Building, The University of Manchester, Manchester M13 9PL, United Kingdom
\end{abstract}

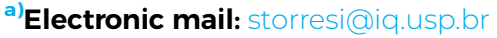

\begin{abstract}
Electroactive materials based on conductive polymers are promising options for tissue engineering and regenerative medicine applications. In the present work, the conducting copolymers of poly (3,4-ethylenedioxythiophene) and poly (D, L-lactic acid) (PEDOT-co-PDLLA) with PEDOT:PDLLA molar ratios of 1:50, 1:25, and 1:5 were synthesized and compared to the insulating macromonomer of EDOT-PDLLA as an experimental control. Bone marrow-derived human mesenchymal stem cells (hMSC-BM) were cultured on the copolymers and the macromonomer thin films inside a bioreactor that induced a capacitive electrical stimulation (CES) with an electric field of $100 \mathrm{mV} / \mathrm{mm}$ for $2 \mathrm{~h}$ per day for 21 days. Under CES, the copolymers exhibited good cell viability and promoted the differentiation from hMSC-BM to osteogenic lineages, revealed by higher mineralization mainly when the contents of conducting segments of PEDOT (i.e., copolymer with 1:25 and 1:5 PEDOT:PDLLA ratios) were increased. The results indicate that the intrinsic electrical conductivity of the substrates is an important key point for the effectiveness of the electric field generated by the CES, intending to promote the differentiation effect for bone cells.
\end{abstract}

Published under an exclusive license by the AVS. https://doi.org/10.1116/6.0001435

\section{INTRODUCTION}

Human mesenchymal stem cells from bone marrow (hMSC-BM) present the unique potential to differentiate into multiple cell types. ${ }^{1}$ Among the strategies available to direct stem cell fate, capacitive electrical stimulation (CES) has been extensively investigated in recent studies, ${ }^{2,3}$ showing its capability to enhance the differentiation of hMSCs into the osteogenic lineage., Piezoelectricity plays an important role in bone tissue; however, it is frequently neglected in regenerative medicine applications. ${ }^{6}$ It has been shown that piezoelectricity can be essential for the formation and regeneration of new bone tissue. ${ }^{6,7}$ When the bone is mechanically stressed, electrical signals are produced which in turn promotes bone growth and remodeling. Therefore, it can be assumed that local electrical signals would affect osteogenesis. ${ }^{8}$ It is widely known that some tissues such as bone, skin, and nerve, among others, are capable of some level of regeneration. ${ }^{9,10}$ In some cases, implants are needed to repair damaged tissues. ${ }^{11,12}$ Often, bone damage is treated with permanent implants (e.g., internal fixators) to replace or assist the remaining tissue. Such implants have limitations, mainly longevity. ${ }^{12}$ In regenerative medicine, to improve tissue repair, cells derived from sources such as patient's bone, nerve, or bone marrow are laboratory-isolated, grown, and placed onto a degradable material or scaffold with appropriate mechanical and physico-chemical properties. ${ }^{13}$ Thus, controlling stem cell fate with conductive thin films based on electroactive polymers and CES is a topic of particular interest. ${ }^{14}$

Electroactive polymers are becoming a platform to study the effect of conductivity on stem cell adhesion, proliferation, and differentiation processes. ${ }^{15}$ Although long-term CES was reported to induce a low degree of cytotoxicity, short-term CES studies showed 
positive effects on stem cell differentiation. ${ }^{16,17}$ Conductivity, reversible oxidation, redox stability, biocompatibility, hydrophilic, threedimensional geometry, and surface topography are desired properties of materials for regenerative medicine applications; ${ }^{18}$ all of those properties are linked to polymer stability in the biological environment. ${ }^{7,14}$ Furthermore, data reported in the literature indicate an increase in the use of biocompatible and electroactive polymers in different disciplines, ${ }^{18}$ including biosensors, controlled therapeutic drug delivery systems, bio-actuators, and tissue engineering. $^{19,20}$

Despite the desirable features mentioned above, it is wellknown that most conductive polymers exhibit low degradability and considerable cytotoxicity, limiting their applications in biomedicine. $^{21,22}$ Conductive polymers tend to be relatively stiff because of $3 \mathrm{D}$ conformational hindrance; consequently, films prepared via electro-polymerization rip easily. ${ }^{14,23,24}$ Besides, poor molecular interaction with cells is the main challenge to be faced for the use of conductive polymers such as biomaterials; even though their biocompatibility can be significantly improved by doping with specific anions or linking to other polymers, electroactive polymers still present low or no biodegradability. ${ }^{14,23}$ This represents a significant problem as the handling properties of the bio-medical products are of key importance to their successful translation from the laboratory to the clinics. In order to overtake this problem, a new copolymer of conducting polymer [poly (3, 4-ethylenedioxythiophene) (PEDOT), and poly (D, L-lactic acid) (PDLLA, a widely recognized biocompatible polymer] was developed. The novelty of the material PEDOT-co-PDLLA is the ability of overtaking the biodegradability problems associated with the cytotoxicity of other conductive polymers while maintaining the desired electroactive and biocompatible characteristics. $^{23-25}$

It was shown in the literature that capacitive electrical stimulation positively influenced hMSC-BM behavior and in vivo enhanced the bone regeneration process. ${ }^{26}$ In the present work, the adhesion, proliferation, and differentiation processes of hMSC-BM on PEDOT-co-PDLLA thin films with different molar ratios under CES were investigated. An in-house bioreactor was used to induce the capacitive electrical stimulus to the hMSC-BM seeded on PEDOT-co-PDLLA thin films, which were submerged in the culture medium. The electrodes in the bioreactor were not in direct contact with the material or the culture medium, which greatly reduced the formation of reactive oxygen species and abrupt $\mathrm{pH}$ variations at the interface of the conducting copolymer and the culture medium that can be harmful to cells. ${ }^{26-28}$ It was hypothesized that CES was able to directly affect the adhesion and proliferation of hMSC-BM seeded on PEDOT-co-PDLLA copolymer. Cell proliferation was investigated with the AlamarBlue assay, DNA PicoGreen assay, and Live/Dead viability assay, while osteogenic differentiation was assessed by Alizarin Red staining (ARS).

\section{EXPERIMENT}

\section{A. Reagents}

The chemicals [2,3-dihydrothiene [3,4-b] [1,4] dioxin-2-yl) methanol (EDOT-OH)], Dulbecco's buffer saline, fibronectin protein, and 3,6-dimethyl-1,4-dioxane-2,5-dione (lactide) were purchased from Sigma-Aldrich. Organometallic catalyst tin
(II)-2-ethylhexanoate was also obtained from Sigma-Aldrich. Toluene (99.5\%), acetonitrile (99.5\%), hexane (98.5\%), chloroform (99.5\%), and methanol (99.5\%) were purchased from Synth-Brazil and were distilled before use. All solutions were prepared with de-ionized (DI) Milli-Q water (18.2 M $\Omega$ ). All solutions were filtered with the Millipore Express PES Membrane $(0.22 \mu \mathrm{m})$ before use.

\section{B. Synthesis of the electroactive macromonomer EDOT-PDLLA and PEDOT-co-PDLLA}

The synthesis method has been already reported in a previous work. ${ }^{29}$ Briefly, the first step of the synthesis was to obtain an electroactive macromonomer of EDOT-PDLLA. 3,6-Dimethyl-1,4-dioxane-2,5-dione (2.76 g, $20 \mathrm{mmol})$, hydroxymethyl EDOT (100 mg, $0.6 \mathrm{mmol}$ ), and tin (II)-2-ethylhexanoate $(0.016 \mathrm{ml}, 0.05 \mathrm{mmol})$ were stirred at $110^{\circ} \mathrm{C}$ with $7 \mathrm{ml}$ of toluene for $24 \mathrm{~h}$. The solvent was removed by distillation under reduced pressure $\left(20 \mathrm{mBar}, 60^{\circ} \mathrm{C}\right)$. The obtained solid product was purified by recrystallization with a (1:4) hexane/methanol mixture, separated by decantation, and vacuum dried until constant mass. The yield obtained from this procedure was $98 \%$. The EDOT-PDLLA was used as a chemical control because it is mainly formed by insulating PDLLA chains.

The second step of the synthesis consisted of obtaining the conducting and partially biodegradable PEDOT-co-PDLLA. For this step, $2.7 \mathrm{~g}$ of the EDOT-PDLLA macromonomer was dissolved in $17.5 \mathrm{ml}$ dried acetonitrile and kept under magnetic stirring at $30{ }^{\circ} \mathrm{C}$ for $2 \mathrm{~h}$. Subsequently, 3,4-ethylenedioxythiophene (EDOT) $(0.06 \mathrm{~g}, 0.42 \mathrm{mmol} ; 0.12 \mathrm{~g}, 0.81 \mathrm{mmol}$; and $0.60 \mathrm{~g}, 4.20 \mathrm{mmol})$ and $\mathrm{NH}_{4} \mathrm{~S}_{2} \mathrm{O}_{8} \quad(0.18 \mathrm{~g}, 0.8 \mathrm{mmol} ; 0.36 \mathrm{~g}, \quad 1.62 \mathrm{mmol} ;$ and $1.80 \mathrm{~g}$, $8.0 \mathrm{mmol}$ ) were added to the reaction vessel to obtain the 1:50, $1: 25$, and 1:5 proportions of PEDOT:PDLLA, respectively, and kept under magnetic stirring at $30^{\circ} \mathrm{C}$ for $24 \mathrm{~h}$. After the reaction medium changed to dark blue, only the soluble fraction was placed in another glass vessel, the solvent was removed by distillation under reduced pressure $\left(20 \mathrm{mBar}\right.$ at $\left.60^{\circ} \mathrm{C}\right)$, and the resultant solid was PEDOT-co-PDLLA. In this study, each copolymer was named PEDOT-co-PDLLA 1:5, 1:25, and 1:50. The copolymer structure and schematic are shown in Fig. 1.

\section{Preparation of thin films of PEDOT-co-PDLLA and EDOT-PDLLA for cell culture}

Round glass slides ( $13 \mathrm{~mm}$ diameter, $0.19-0.23 \mathrm{~mm}$ thick, Academy) were ultrasonically cleaned and degreased followed by air drying. To modify the cleaned surfaces, a solution at $20 \mathrm{mg} / \mathrm{ml}$ $(\mathrm{w} / \mathrm{w})$ in the chloroform of EDOT-PDLLA and PEDOT-co-PDLLA in the molar proportions PEDOT:PDLLA 1:50, 1:25, and 1:5 were deposited onto glass slides by spin coating using an Ossila spin coater, operating at $3000 \mathrm{rpm}$ during $30 \mathrm{~s},(24 \pm 1)^{\circ} \mathrm{C}$, and $(20 \pm 5) \%$ of relative humidity. All the glasses covered with polymers were then sterilized using ultraviolet (UV) light for $45 \mathrm{~min}$ each side. This sterilization method was chosen because it can ensure the maintenance of original material properties without severe impairment to your mechanic and conductive performance. UV light has been commonly applied for the sterilization of medical products because of its simple and uniform sterilization without heat generation. Previous work published by da Silva et al. ${ }^{25}$ 
(a)

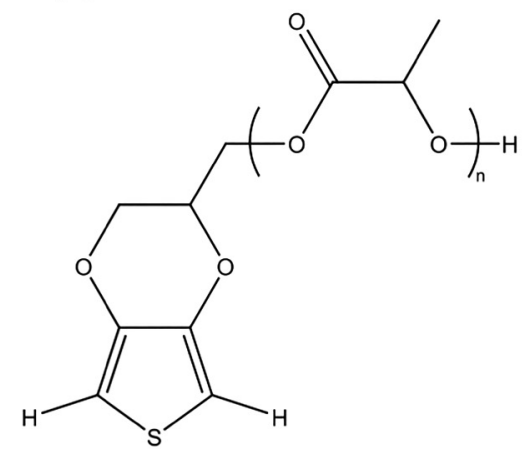

(b)

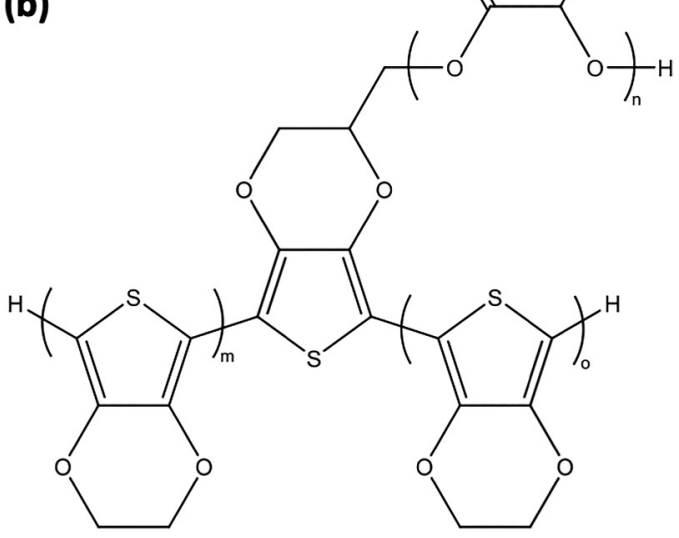

FIG. 1. Chemical structure of (a) the electroactive macromonomer of EDOT-PDLLA and (b) PEDOT-co-PDLLA copolymer, respectively.

has already shown the surface roughness and water contact angles for the same conductive copolymers applied to assays using embryonic stem cells and they were the same before and after sterilization process.

\section{Cell culture}

The hMSC-BMs were obtained commercially (PT-2501, Lonza Group Ltd., UK). Frozen vials of cells were thawed, cultured, and expanded to reach the desired confluence based on the instructions provided by the company. Cells of passage 4 were cultured in the growth medium (GM) consisting of Dulbecco's modified Eagle's medium with $4500 \mathrm{mg} / \mathrm{l}$ glucose, L-glutamine, and sodium bicarbonate, without sodium pyruvate, supplemented with $10 \%$ fetal bovine serum and $1 \%$ penicillin/streptomycin (10 000 units $/ \mathrm{ml})$; all were obtained from Sigma-Aldrich (UK). The cells were maintained at $37^{\circ} \mathrm{C}$ and $5 \% \mathrm{CO}_{2}$ in a humidified incubator. $100 \mu \mathrm{l}$ of cell suspension containing $2 \times 10^{4}$ cells was seeded onto the modified surface glass slides. After $1 \mathrm{~h}$ of cell seeding, GM was added to each well carefully from the wall of the well plate to minimize the turbulence of the medium in the well. One day after initial cell seeding (termed day 1), half of the samples were refreshed with GM. The nonstimulated control group was incubated in a separate incubator with identical conditions but without electrical stimulation. The media were changed every 3 days.

\section{E. In vitro electrical stimulation}

An in-house-made 8-well polytetrafluoroethylene bioreactor was used to induce CES. In more details, the bioreactor consists of three embedded stainless-steel electrodes, i.e., two positive electrodes located on both sides of the bioreactor and one negative electrode located in the middle of the bioreactor that separates the four wells on each side of the bioreactor, creating an inverted symmetry well configuration (Fig. S1). ${ }^{73}$ Computational simulation results revealed a homogeneous electrical field (EF) and no electrical current inside the culture well (see supplementary information $^{73}$ for the COMSOL modeling methods and results).

Before the use, the bioreactor was sterilized in a steam autoclave. On the first day, the cell-seeded glass slides were transferred to the bioreactor using sterilized tweezers. GM was added to respective wells of the experimental group and secured with the lid of standard cell culture plates (Sigma-Aldrich, UK). The bioreactor was connected to a calibrated Triple Output Programmable Direct Current Power Supply (Model 9130; B\&K Precision Corporation, Yorba Linda, CA, USA). Two hours per day of electrical stimulation with a constant potential of $3.5 \mathrm{~V}$ was applied to the bioreactor, leading to a $28 \mathrm{mV} / \mathrm{mm} \mathrm{EF}$ according to our modeling results. The experimental assembly was incubated under standard cell culture conditions during the electrical stimuli (ES). The media were changed every 2 days. All assays were performed immediately after the last exposure to the EF. The electrical field distributions on the glass slide surface with a PEDOT-co-PDLLA film inside the culture medium were calculated by modeling (Fig. S2a) ${ }^{73}$ and are plotted in Fig. S2b. ${ }^{73}$

Samples were harvested at nine time points, on the 1st, $3 \mathrm{rd}$, 5 th, 7th, 9th, 11th, and 14th day, for the AlamarBlue assay $(n=3)$, viability and morphology assessment using LIVE/DEAD cell viability assay $(n=2)$, and on the 21 st day for cell lysate collection for calcium concentration using Alizarin Red staining quantification assay $(\mathrm{n}=4)$ and DNA PicoGreen assay $(\mathrm{n}=4)$.

\section{EXPERIMENTAL METHODS}

\section{A. AlamarBlue assay}

In order to assess the cellular metabolic activity, capacitive electrical stimulation groups over a glass slide, EDOT-PDLLA and PEDOT-co-PDLLA 1:50, 1:25, and 1:5, respectively, were assayed at $1 \mathrm{st}, 3 \mathrm{rd}$, 5th, 7th, 9th, 11th, and 14th day using the AlamarBlue assay. Briefly, a $100 \mu \mathrm{l}$ working solution of $10 \%$ AlamarBlue (Thermo Fisher Scientific, UK) in GM was added directly to the 
sample wells and then incubated at $37^{\circ} \mathrm{C}$ for $60 \mathrm{~min}$. Following incubation, three $200 \mu \mathrm{l}$ aliquots were transferred from each sample into a clear 96-well plate. Fluorescence readings were taken using a FLUOstar OPTIMA microplate reader (BMG Labtech) at $560 \mathrm{~nm}$ excitation and $590 \mathrm{~nm}$ emission. After the assay, the samples were incubated with fresh GM. The same samples were measured at each time point.

\section{B. Live/dead cell viability assay}

Cell viability and morphology on the glass slides covered with copolymers and macromonomer before and after CES were assessed by a fluorescence-based LIVE/DEAD cell viability assay (Thermo Fisher Scientific, UK). The assay was performed at 1st, 7th, and 14th days. A $4 \mathrm{mM}$ calcein-AM in anhydrous dimethyl sulfoxide (DMSO) and $2 \mathrm{mM}$ ethidium homodimer-1 in DMSO/ $\mathrm{H}_{2} \mathrm{O}$ 1:4 (v/v) in phosphate-buffered saline (PBS) were added to each sample and incubated for $30 \mathrm{~min}$, washed again with fresh $\mathrm{PBS}$, and visualized using fluorescence light microscopy (Nikon Eclipse 50i, equipped with LUCIA GF-DXM1200 version 4.82 imaging software).

\section{DNA analysis by fluorometric detection}

DNA detection was performed in a 96-multiwell plate for the samples and standards. A standard curve was generated using 5$125 \mathrm{ng}$ of double-stranded calf thymus DNA, dissolved, and diluted in either PBE buffer $\left(100 \mathrm{mM} \mathrm{Na}_{2} \mathrm{HPO}_{4}, 5 \mathrm{mM}\right.$ EDTA, $p \mathrm{H}$ 7.5) or TN buffer ( $50 \mathrm{mM}$ Tris, $150 \mathrm{mM} \mathrm{NaCl}, p \mathrm{H}$ 7.5) for cells samples detached by the vortex process. In a 96 -well plate, duplicate standards and samples were analyzed according to the supplier procedure. Samples were read with a Molecular Devices Gemini II fluorescence plate reader at $360-\mathrm{nm}$ excitation and $460-\mathrm{nm}$ emission, with a 420 -nm cut-off filter. Results were tabulated using Molecular DeVices SOFTMAX PRO 3.1 software.

\section{Alizarin Red staining quantification assay}

The level of bone mineralization and calcium deposition in the cell culture was determined by ARS. ${ }^{30,31}$ At 21st day, the control and experimental groups were washed twice with PBS and fixed with $10 \%$ formalin solution (Sigma-Aldrich, UK) for $30 \mathrm{~min}$ at room temperature. ${ }^{31}$ The fixed cells were washed three times with DI water. The samples in the well plate were stained $1 \mathrm{~h}$ with $2 \% \mathrm{w} / \mathrm{v}$ Alizarin Red staining solution (Sigma-Aldrich, UK) in DI water and maintained at $p \mathrm{H}$ 4.1-4.3. The staining solution was removed, and the samples were washed five times with DI water. For a quantitative analysis, the red-stained calcium contents were dissolved at $37^{\circ} \mathrm{C}$ for 30 min with gentle shaking using $300 \mu \mathrm{l}$ of $10 \% \mathrm{w} / \mathrm{v}$ cetylpyridinium chloride (Sigma-Aldrich, UK) in PBS. Subsequently, three $50 \mu \mathrm{l}$ replicates of the dissolved solution were pipetted from each sample into a clear 96-well plate. Absorbance readings were taken using a Synergy II plate reader (Biotek Instruments Ltd.) at $550 \mathrm{~nm}$.

\section{RESULTS AND DISCUSSIONS}

\section{A. Live/dead assay}

Cell viability is an important parameter for any in vitro cell assay. Culture conditions and experimental treatments can affect cell viability by directly or indirectly inducing cytotoxicity, apoptosis, and/or necrosis. ${ }^{32}$ A hallmark of viable cells is an intact plasma membrane and cellular metabolic activity. ${ }^{33}$ These two features form the basis of this live and dead cell assay. Live cells are identified on the basis of intracellular esterase activity that generates green fluorescence. ${ }^{34}$ Dead cells are identified by the lack of esterase activity and nonintact plasma membrane that allows red dye staining of the cell nucleus. Live/dead assays for 1st, 7 th, and 14th days in the absence [Fig. 2(a)] and presence [Fig. 2(b)] of CES were performed. These results demonstrated that copolymers showed good cell viability and proliferation for all studied surfaces. Figure 2(a) shows an increasing spread of cells onto all surfaces with time, indicating cell proliferation throughout the studied period in the absence of CES. On the other side, EF caused a reduction in the cell coverage over all surfaces after seeding for $24 \mathrm{~h}$, and the same was observed at 7 and 14 days [Fig. 2(b)]. Moreover, hMSC-BM under CES was disconnected with elongated cell morphology [Fig. 2(b), 14th day], indicating a reduced cell-cell interaction, which was in sharp contrast to what was observed in the absence of EF [Fig. 2(a)]. The results showed that the cellular distribution was decreased even though the mineralization of the extracellular matrix over the copolymers with higher PEDOT content had enhanced. To understand the relationship between cell differentiation and their proliferation behavior under CES, an analysis of cell metabolic behavior and DNA expressions levels are also very important.

\section{B. Cell metabolic behavior}

In order to evaluate the influence of EF on hMSC-BM metabolism, AlamarBlue reduction was measured in the absence [Fig. 3(a)] and presence [Fig. 3(b)] of the CES from the 1st to the 14th day. Figure 3 shows that the fluorescence intensity of AlamarBlue reduction increased steadily with time for both conditions. Figure 3(a) shows that at 1st day, the metabolic activity of hMSC in the absence of CES over the studied materials presented comparable behavior (i.e., there was no significant difference in fluorescence intensity between them at this time point). However, from the 3rd day, the stem cell metabolic activity over the copolymer 1:50 overtake all the others, whereas for EDOT-PDLLA and copolymers 1:25 and 1:5, the metabolic activity was comparable between them until 14th. On the other hand, when the cells' metabolic behavior in the presence of CES is analyzed in detail [Fig. 3(b)], a higher metabolic activity over copolymers 1:25 and 1:5 from the 1st to the 5th day than for EDOT-PDLLA and copolymer 1:50 is observed. Moreover, from the 7th day, the cells over copolymers 1:25 and 1:50 had higher metabolic activity than 1:5. It is also observed that from the 7th day, there was a constant increase in the cell's metabolism over the copolymer 1:50, which overtakes all the others only at the 14th day. For EDOT-PDLLA, it is observed that the cells' metabolic activity over this material was lower in the whole analyzed range, which overtakes all the others 
(a)

PEDOT-co-PDLLA 1:50
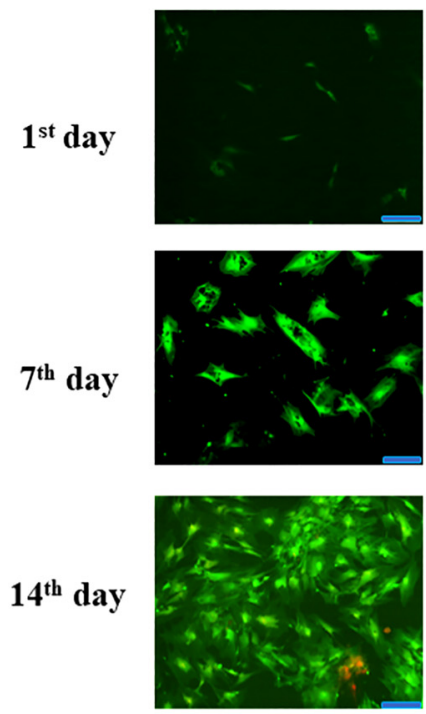

PEDOT-co-PDLLA 1:50
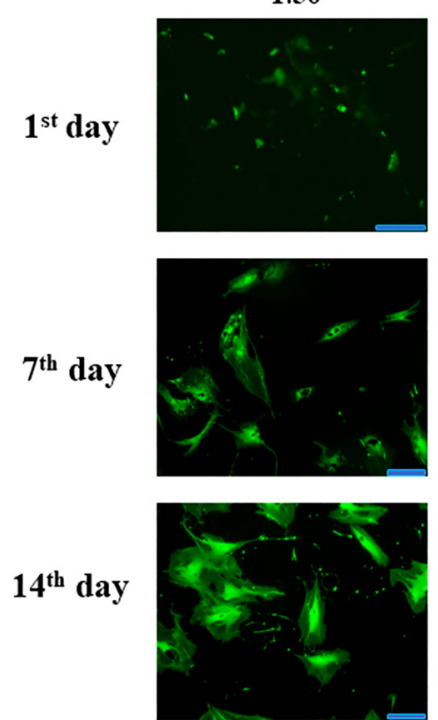

PEDOT-Co-PDLLA 1:25
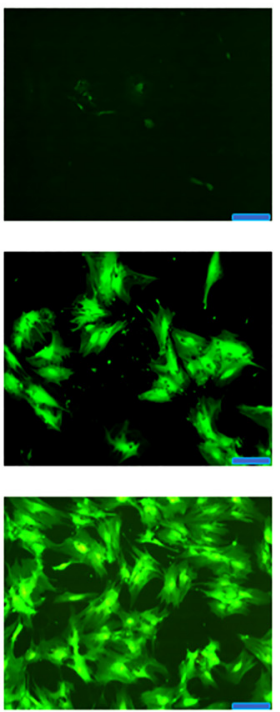

(b)

PEDOT-co-PDLLA 1:25
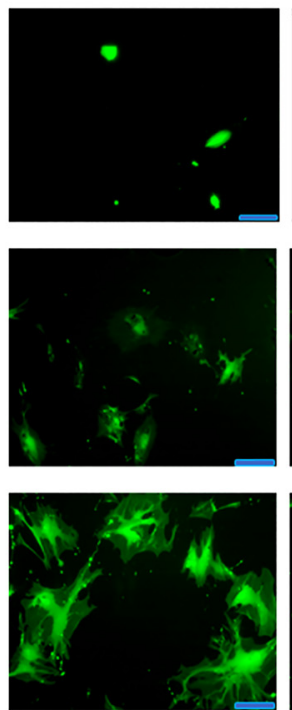

PEDOT-Co-PDLLA $1: 05$
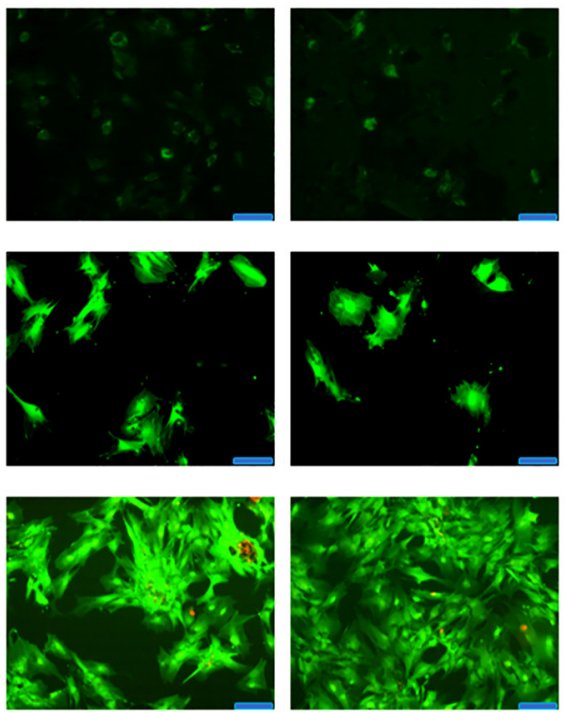

PEDOT-Co-PDLLA 1:05
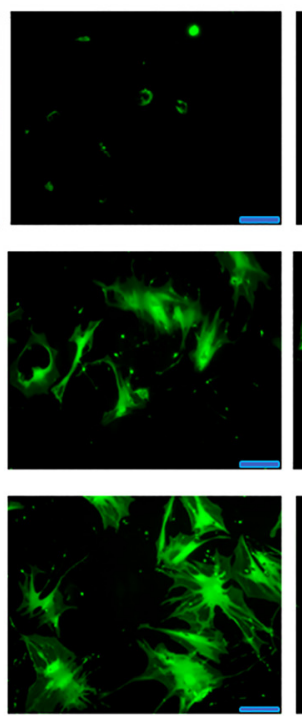
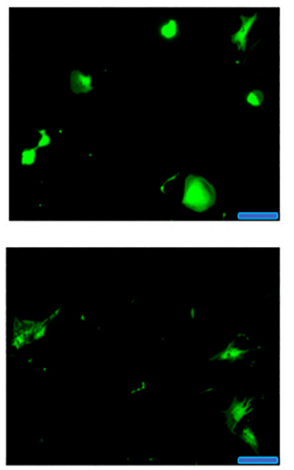

EDOT-PDLLA
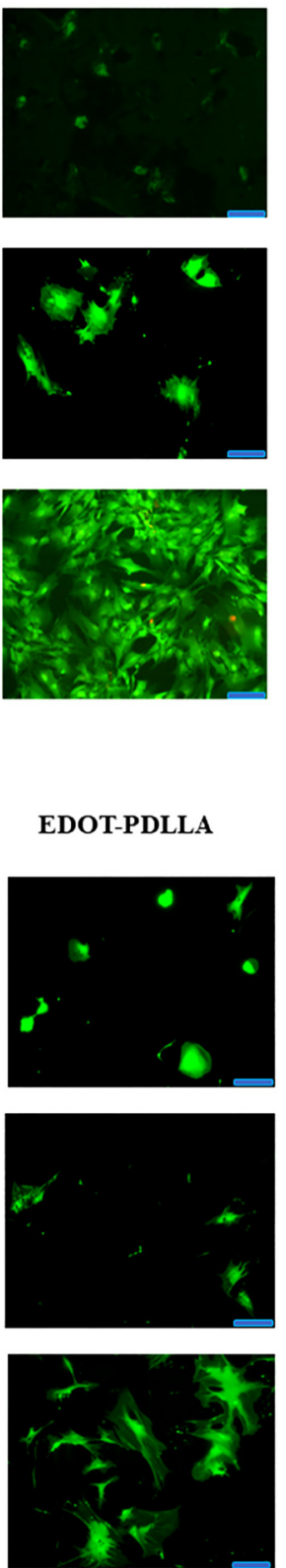

FIG. 2. Live/dead cell assay over PEDOT-co-PDLLA 1:50, 1:25, 1:5, and EDOT-PDLLA, respectively, in the absence (a) and presence (b) of capacitive electrical stimulation at $28 \mathrm{mV} / \mathrm{mm}$ performed for $2 \mathrm{~h}$ per day, respectively. Live cells were stained with green and dead cells were stained with red. Scale bars $=100 \mu \mathrm{m}$.

only at the 11th day. EF effects are not neutralized after the exposition of $2 \mathrm{~h}$ per day, causing a decrease in cell metabolic activity if compared with the absence of CES. Furthermore, there are differences to the outcomes showed off for the spread cell over biomaterials as much in the absence as in the presence of the CES The same is observed in DNA expression. In contrast, the ARS assay showed off over the copolymers with a higher conductive backbone structure (PEDOT-co-PDLLA 1:25 and 1:5) presented 


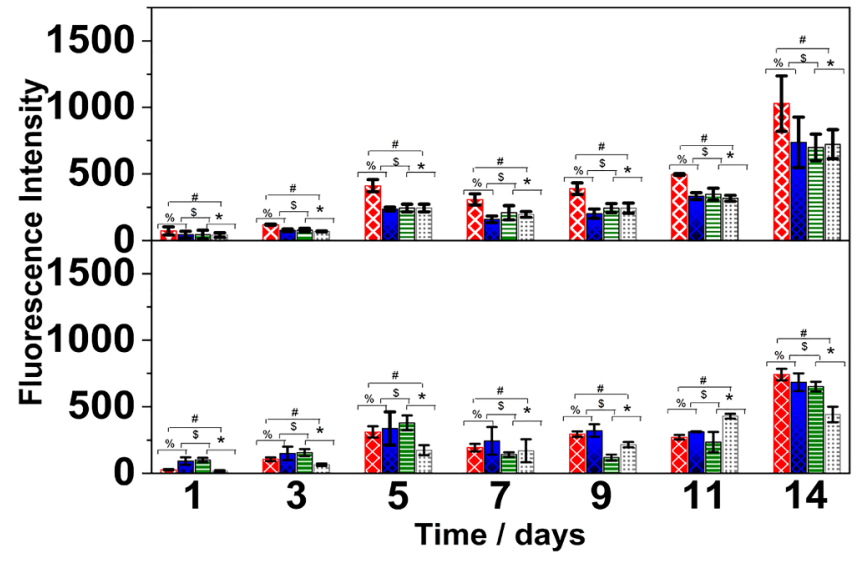

FIG. 3. AlamarBlue metabolic activity of hMSCs over PEDOT-co-PDLLA $1: 50$

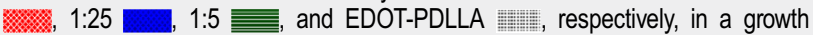
medium in the absence (a) and presence (b) of capacitive electrical stimulation at $28 \mathrm{mV} / \mathrm{mm}$ performed for $2 \mathrm{~h}$ per day. The significance of the results was analyzed using two-way ANOVA. Data are expressed as the means \pm standard deviation (SD) of measurements, $n=3\left({ }^{*}, \% \$, \% p<0.05 ;{ }^{* *}, \% \% p<0.01\right.$; and *\#, \#p<0.001)

higher calcium deposition levels, indicating that intrinsic conductivity of the copolymers plays a key role function in promoting the osteogenic differentiation of hMSC-BM, since in the insulating polymer (EDOT), the calcium levels were smaller. In this context, Khatib and co-workers ${ }^{35}$ observed that ES promoted enhanced intracellular calcium increase mediated by phospholipase $\mathrm{C}$ activation in human osteoblasts. The same was observed by Leppik, ${ }^{36}$ where ES has been shown to promote bone healing and regeneration in both animal experiments and clinical treatments. On the other hand, what da Silva et al. ${ }^{25}$ proposed is based on the surface charge density promoted electrostatic interactions between the scaffold of the conductive copolymer and the anchoring proteins of cells that trigger cell signaling that models cell spreading, migration, and differentiation. The orientation and adsorption rate of serum proteins in the substrate are also affected by their surface charge, interfering in the activation of anchoring protein. Although it is not clear yet, some explanations were proposed on how electrical stimulation could alter calcium ion concentration in the cell. Based on data reported in the literature, a discussion much more deeply was done in the section about the osteogenesis metabolic cell process.

\section{DNA expression levels}

The effect of cellular stress on hMSC-BM adhesion and proliferation on different surfaces submitted to the CES were assessed through the quantification of the DNA content with PicoGreen, as shown in Fig. 4. These results were obtained after 21 days of culture in the growth medium under the CES with a regime of a $28 \mathrm{mV} / \mathrm{mm}$ electric field for $2 \mathrm{~h}$ per day. For comparison, the samples without CES were also included in the study.

Interestingly, in the absence of the CES [Fig. 4(a)], the hMSC DNA content (correlating to total cell number) on PEDOT-co-PDLLA 1:25 was higher than on all the other substrates. The expressed values for DNA content were 46.00, 91.00, 69.00, and 63.00 ng ml${ }^{-1}$ for PEDOT-co-PDLLA 1:50, 1:25, and $1: 5$, and EDOT-PDLLA, respectively. In contrast, under CES [Fig. 4(b)], reduced DNA expression levels were observed in all samples, with values of the DNA content of 19.00, 18.00, 21.00, and $24.00 \mathrm{ng} \mathrm{ml}^{-1}$ for the respective PEDOT-co-PDLLA 1:50, 1:25, and 1:5, and EDOT-PDLLA. Several cellular effects are understood to be mediated by the EF applied in the CES through an electrocoupling mechanism. ${ }^{37}$ The basis of invoking such an indirect effect emerges from the high resistance imparted by the plasma membrane, which prevents the penetration of electric stimuli, regardless of the conducting nature of the cytoplasm. ${ }^{38}$ One of the possible electro-coupling mechanisms involves asymmetric redistribution/diffusion of electrically charged cell-surface receptors in response to an EF applied, which further activates numerous (a)

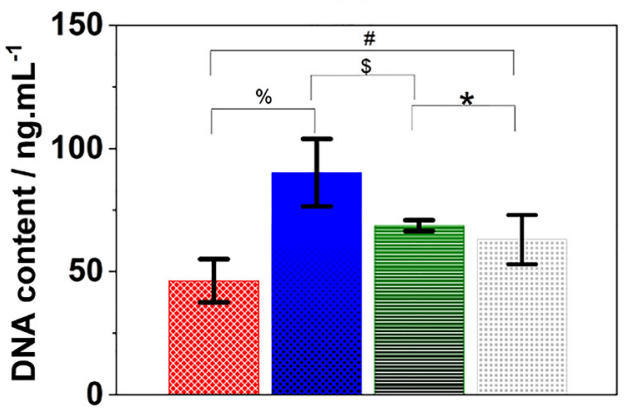

(b)

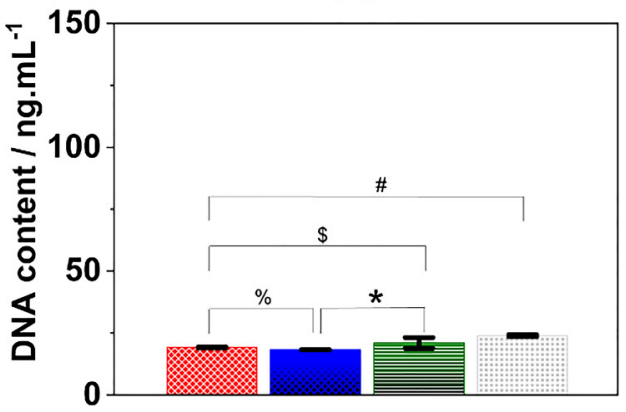

FIG. 4. DNA content measured at 21 days by the PicoGreen assay for hMSC-BM in the absence (a) and presence (b) of capacitive electrical stimulation at $28 \mathrm{mV} / \mathrm{mm}$ performed for $2 \mathrm{~h}$ per day in the growth medium over PEDOT-co-PDLLA 1:50 results was analyzed using two-way ANOVA. Data are expressed as the means \pm standard deviation (SD) of measurements, $n=4\left({ }^{*}, \% \$, \% p<0.05 ;{ }^{*}, \% \% p<0.01 ;\right.$ and *\#, \#p <0.001). 
downstream signaling cascades. ${ }^{39,40}$ Another possible mode is via the voltage-gated calcium channel activation (VGCC) by cell membrane depolarization, which leads to the most consistently occurring cellular response to electric stimuli, i.e., the elevation of intracellular calcium ion concentration. ${ }^{39}$ It is very interesting because the efficacy of substrate conductivity and capacitive electrical stimulation acting in synergy could direct hMSC-BM differentiation toward osteogenic lineage. ${ }^{41}$

\section{Osteogenesis cell differentiation}

The growth of the new bone tissue on a biocompatible material in regenerative medicine requires various factors that need to be optimized and controlled. Utilizing the piezoelectric nature of bone, ${ }^{5,7}$ CES can be an additional tool to control osteogenesis. In order to evaluate the hMSC-BM differentiation toward osteogenic lineage under CES, Alizarin Red stained images were obtained to identify the calcified nodules [Figs. 5(a) and 5(b)]. In the absence of CES [Fig. 5(a)], lightly stained areas that were likely caused by the cellular metabolism of calcium and magnesium were observed; in contrast, under CES [Fig. 5(b)], significantly more calcified nodules were seen, indicating the initiation of mineralization of the extracellular matrix.

In order to better assess the osteogenic effect of CES, ARS was extracted by cetylpyridinium chloride and subsequently quantified [Figs. 5(c) and 5(d)]. Figure 5(c) shows that the copolymers (PEDOT-co-PDLLA) and the macromonomer (EDOT-PDLLA) without CES had comparable amounts of extracted dye. In contrast [Fig. 5(d)], the thin films of copolymers under capacitive electrical stimulation presented higher calcium deposition levels, especially for the copolymers with the higher molar ratios of PEDOT (PEDOT-co-PDLLA 1:25 and 1:5). As already reported in a previous publication, cyclic voltammetry confirmed the electroactive character of the materials. ${ }^{25}$ Conductivity measurements were performed via electrochemical impedance spectroscopy, and the bulk conductivities of PEDOT-co-PDLLA 1:5, 1:25, and 1:50 were $5.35 \times 10^{-5}, 2.07 \times 10^{-5}$, and $4.19 \times 10^{-8} \mathrm{~S} \mathrm{~cm}^{-1}$, respectively. ${ }^{25}$ This feature perhaps indicates that the intrinsic conductivity of the copolymers plays a key role in the differentiation process from hMSC-BM to bone cells under CES. It should be noted that the trends in normalized calcium deposition were similar to those of total deposition on day 21, suggesting that improvements in the calcium levels were not affected by the number of cells (Fig. S4). ${ }^{73}$ Interestingly, because the mature bone matrix resulted in differentiated cell death, a lower number of cells led to higher normalized calcium deposition. These results supported that the electroactive surfaces improved osteogenesis.

The use of an electroactive and partially biodegradable polymer with this experimental setup is a novelty and little work has been reported in the literature. Data reported in our previous publication $^{23}$ showed that in vitro biodegradability of PEDOT-co-PDLLA in the molar proportions mentioned above was evaluated using proteinase K. After 35 days, 1:5, 1:25, and 1:50 copolymers reached $45.9 \pm 4.1,35.6 \pm 2.0$, and $29.2 \pm 2.0 \%$ weight losses, respectively. ${ }^{23}$ Noncytotoxicity was assessed by adhesion, migration, and proliferation assays using embryonic stem cells (E14.tg2a); excellent neuronal differentiation was observed.
PEDOT-co-PDLLA presented surface chemistry and charge density properties that make them potentially useful as scaffold materials in different fields of applications, especially for tissue engineering. ${ }^{25}$ With regard to the electroactive properties of copolymers, some studies indicated that electroactive surfaces may promote cell differentiation, ${ }^{42,43}$ and experimental evidence suggested one plausible mechanism that involves an induced electric field in the cell membrane causing alterations in the transmembrane potential. ${ }^{44-46}$ The potential difference across the cell membrane originates from the interaction between the intra- and extracellular ionic concentration, ${ }^{39}$ and it is regulated through ion channels, pumps, and transporter proteins. ${ }^{47}$ When an external EF is applied, the induced electric field in the cell membrane can cause modification of its potential, which in turn can increase the activity of sodium, potassium, or calcium channels and alter the enzyme activity of phosphates containing the voltage-sensor domain. ${ }^{48,49}$ Therefore, the EF produced by CES may also induce the differentiation process of stem cells to other tissue types. The intrinsic conductivity of the copolymers, mainly those with higher conducting segments in their backbone structure (1:25 and 1:5), could potentialize the EF effect on ion channels and enzyme activity in the hMSC-BM, based on calcium deposition observed on ARS results. Our results supported the osteogenesis of hMSC-BM from CES, which can be caused by the induced EF that may trigger a variety of intracellular signaling events involving the charge redistribution and the ion flow, including signal propagation via $\mathrm{Ca}^{2+}$, gap junctions, or even proteinprotein interactions, ${ }^{39,47,49}$ inducing calcium deposition in the extracellular matrix. ${ }^{43,50}$ These data demonstrated that the conductive copolymers' thin films promoted the osteogenic differentiation of hMSC-BM through elevated ARS and further suggested the great potential of PEDOT-co-PDLLA for bone tissue engineering applications.

\section{E. Osteogenesis metabolic cell process}

It is widely known that electrical signals are sensed and converted into biochemical cues by multiple pathways within the cells, resulting in various biological responses. ${ }^{51-53}$ The activation of signal transduction pathways is considered as the possible mechanism by which the CES applied may express biological responses and exert control over cellular functions. ${ }^{40,41} \mathrm{~A}$ major cellular signal transduction biological pathway, which governs the transcription of specific mRNAs in response to external stimulation, such as ES, is the activation of the mitogen-activated protein kinase (MAPK) cascades. ${ }^{54}$ The MAPKs are proteins of serine/threonine kinases that control intracellular metabolism events in response to extracellular stimulations. ${ }^{54}$ The sequential activation of protein kinases within these cascades (extracellular signal-regulated kinases: ERK1/2 and ERK5, Jun amino-terminal kinases: JNK, p38MAPK) mediates numerous important cellular biological responses, including proliferation, differentiation metabolism, cell cycle progression, and apoptosis relying on the time of ES and the type of cell. ${ }^{47}$ The ES inducing MAPK activation was documented in endothelial angiogenic response and in HL-60 (human promyelocytic leukemia cell line) differentiation. ${ }^{41,47}$ Mechanistically, cell motility and wound healing responses elicited by electrical current gradients take place through the dynamic mediation of PI $(3) \mathrm{K} \gamma$ 
(a)

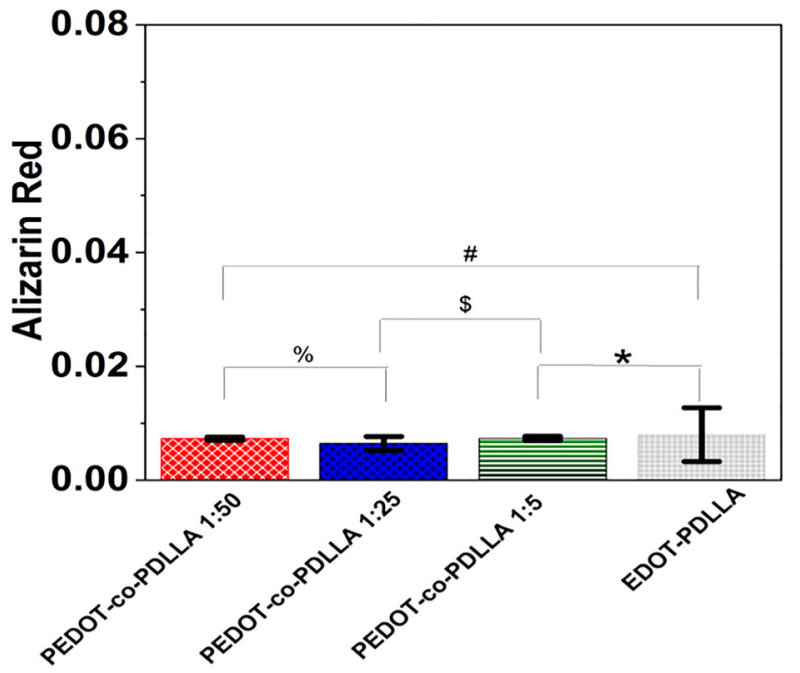

PEDOT-Co-PDLLA

1:50
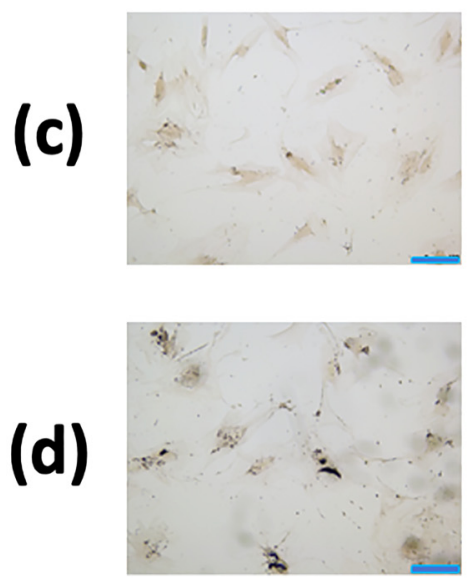

PEDOT-co-PDLLA

1:25
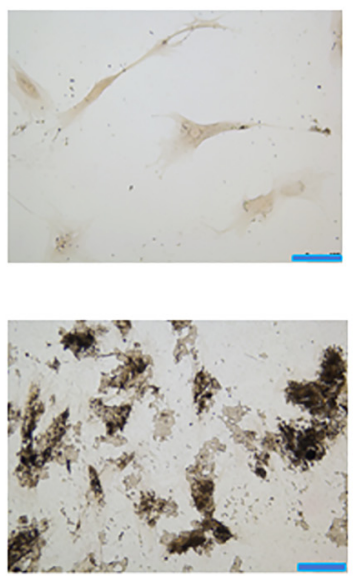

(b)

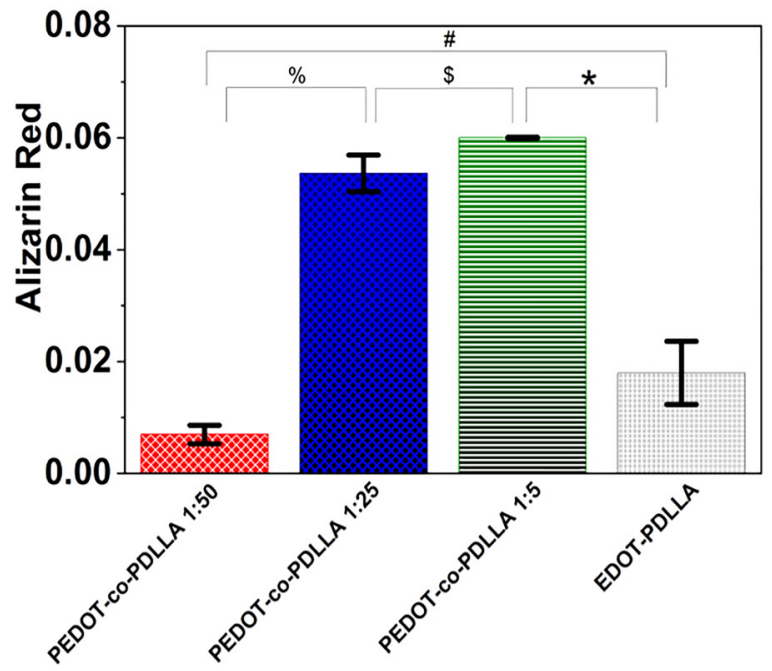

PEDOT-Co-PDLLA 1:05
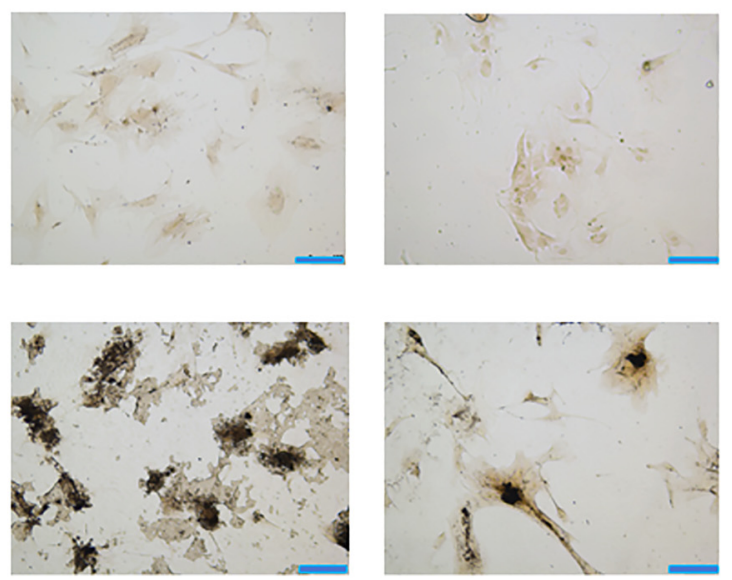

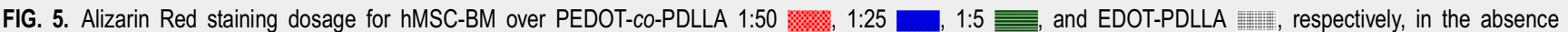
(a) and presence (b) of capacitive electrical stimulation. All stimuli were performed at $28 \mathrm{mV} / \mathrm{mm}$ during $2 \mathrm{~h}$ per 21 days. The significance of the results was analyzed using two-way ANOVA. Data are expressed as the means \pm standard deviation (SD) of measurements, $n=6$ ( ${ }^{*}$ and $\% p<0.05, \$ p<0.01$, and \#p<0.001). Optical microscopy image of ARS-stained hMSC-BM over PEDOT-co-PDLLA 1:50, PEDOT-co-PDLLA 1:25, PEDOT-co-PDLLA 1:5, and EDOT-PDLLA in the growth culture medium in the absence (c) and in the presence (d) of capacitive electrical stimulation, respectively. There were no significant mineral deposits on the confluent monolayer in the absence of capacitive electrical stimulation, whereas in the presence of it, small, densely stained nodules appeared from and coalesced into a continuous matrix. Scale bars $=100 \mu \mathrm{m}$.

(phosphoinositide 3-kinase) and PTEN (phosphate and tensin homolog) signaling. ${ }^{55}$ An accelerated and progressive enhancement in the phosphorylation of extracellular-signal-regulated kinase, p38 MAPK, Src, and Akt on Ser 473 site was distinctly observed in cells undergoing electrotaxis. ${ }^{41}$ It also was reported that the applied lowintensity $0.1 \mathrm{~ms}$ electrical current could induce a transient and lowlevel activation of the p38-p53 pathway, which is implicated to play significant roles in the annihilation of malignant tumors and in the 


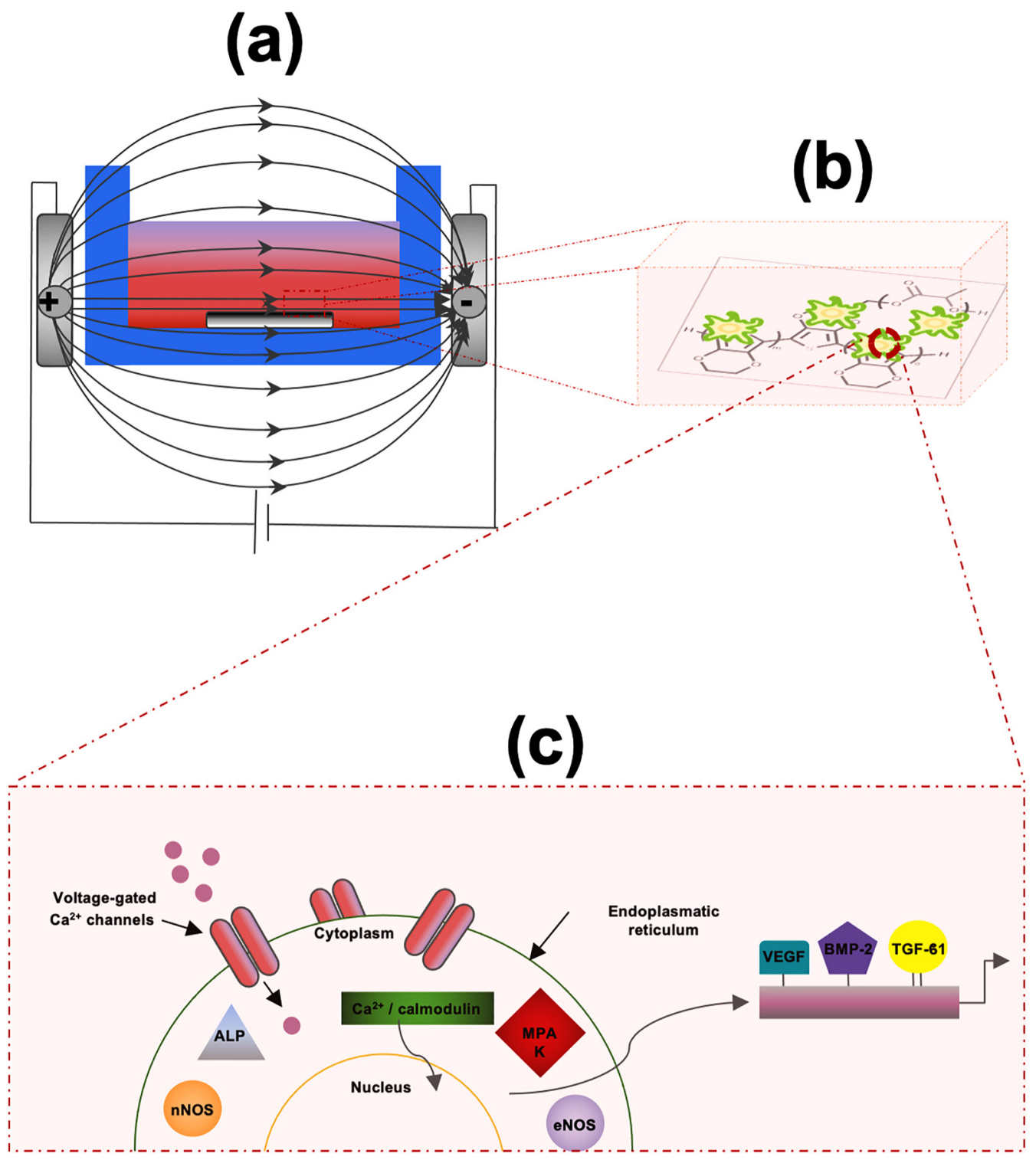

FIG. 6. Schematic of the (a) electric field applied at $28 \mathrm{mV} / \mathrm{mm}$ on the bioreactor with a seeded cell, (b) enlargement of the selected area with attached hMSC-BM over PEDOT-co-PDLLA, and (c) intracellular metabolic activity behavior under capacitive electric stimulation, respectively.

downregulation of inflammatory cytokine responses and metabolism. The cellular orientation and movement of adult stromal cells in response to ES were observed to be linked to the activation of PI3K and ROCK signaling pathways. ${ }^{56}$ However, the orientation and movement of hMSC-BM over EF due to CES applied did not take place in the present study. A schematic of the (a) EF applied at $28 \mathrm{mV} / \mathrm{mm}$ on the bioreactor with the seeded cell, (b) enlargement of the selected area with attached hMSC-BM over PEDOT-co-PDLLA, and (c) intracellular metabolic activity behavior under CES, respectively, is presented in Fig. 6.
Although a possible trend to osteogenic lineage under CES, some studies demonstrate that the EF applied could induce an increased intracellular $\mathrm{Ca}^{2+}$ produced by VGCC. This activation may lead to multiple regulatory responses, including the increased nitric oxide levels produced through the action of the two $\mathrm{Ca}^{2}$ ${ }^{+} /$calmodulin-dependent nitric oxide synthases (NOS), neuronal NOS, and endothelian NOS. Increased nitric oxide levels typically act in a physiological context through an increased synthesis of cyclic guanosine $3^{\prime}, 5^{\prime}$-monophosphate (cGMP) and the subsequent activation of the protein kinase G. ${ }^{51,57,58}$ Nitric oxide reacts with 
superoxide to form peroxynitrite, a potent nonradical oxidant, ${ }^{55,59}$ which can form hydroxyl and $\mathrm{NO}_{2}$ radicals. ${ }^{60}$ The rise in oxidative stress markers parallels the rise in nitric oxide, suggesting a peroxynitrite-mediated mechanism. ${ }^{61-64}$ Peroxynitrite could lead to DNA cell damage and enable their proliferation, ${ }^{64-66}$ producing a reduced spread over conductive copolymers. In order to better understand DNA content results, the cellular metabolic behavior in the absence and presence of the CES must be further analyzed.

The EF effects caused by CES on cell proliferation were widely reported and it included both inhibitory and stimulating effects, depending on the cell type and exposure conditions. ${ }^{67-69}$ Low-frequency EF could actuate on the morphogenesis of mammalian embryo, wound healing, or tumor. ${ }^{41}$ For in vitro cultures, proliferation was observed for various cell types (HL-60 leukemia cells, Rat-1 fibroblasts, and WI-38 diploid fibroblasts) when also exposed to low-frequency EF. ${ }^{41}$ Nevertheless, under identical exposure conditions, unexpected DNA strand breaks in later hours were noticed suggesting that the EF exposure caused a temporary mitogenic effect, followed by a loss of DNA integrity. ${ }^{69}$ In agreement with the mitogenic effect mentioned above, the cell coverage analysis showed a decreased spread over time under CES (Fig. S3), ${ }^{73}$ even though a positive effect on osteogenesis was observed. Furthermore, reductions in the number of cells were observed at the same EF applied (Fig. S4). ${ }^{73}$ Hence, from a pathogenic point of view, this study showed that short-term exposures induced differentiation, whereas prolonged exposures could interrupt the cell cycle by causing DNA damage. ${ }^{69}$ Thus, exposing cells to the EF for a shorter time is a viable way to enhance proliferation and differentiation without inducing undesired DNA damage. Therefore, how DNA damage occurs and how cell differentiation from hMSC-BM to bone cells takes place need to be further investigated. Reported data in the literature show that, in osteogenic stimulation, voltagegated calcium channel stimulation leads to an increase in intracellular $\mathrm{Ca}^{2+}$, acting, in turn, to stimulate the two calcium/calmodulindependent nitric oxide synthases, and an increase in nitric oxide. ${ }^{70}$ An enhancement of the intracellular $\mathrm{Ca}^{2+}$ level can drive to osteogenic differentiation. ${ }^{5,71}$ Nevertheless, bone differentiation of hMSC-BM needs other biological responses to take place. In the case of cell proliferation, nitric oxide may act in pathophysiological responses to CES exposure, by acting as a precursor of peroxynitrite, producing both oxidative stress and free radical breakdown products. ${ }^{66}$ The biologicals signaling mentioned above seems to induce single-stranded DNA breaks, ${ }^{72}$ which could influence cell spread over studied materials at the EF applied.

\section{CONCLUSIONS}

Both, the macromonomer EDOT-PDLLA insulator and the conducting PEDOT-co-PDLLA copolymers, provided a biocompatible microenvironment for the viability and proliferation of hMSC-BM. Even though the adhesion and proliferation of hMSC-BM onto all surfaces in the absence of capacitive electrical stimulation were better, no extracellular bone mineralization process was observed. On the other hand, under capacitive electrical stimulation, the copolymers exhibited good biocompatibility and a great potential to induce the differentiation process from hMSC-BM to osteogenic lineage. The results of ARS demonstrated that the bone mineralization process of hMSC-BM was increased in copolymers with a higher amount of conducting segments (i.e., PEDOT-co-PDLLA 1:25 and 1:5), indicating that the intrinsic electrical conductivity of the substrates plays an important role in the effectiveness of the electric field generated by the capacitive electrical stimulation, intending to promote the differentiation effect for bone cells. This remarkable result of copolymers in promoting the effect of inducing osteogenesis under capacitive electrical stimulation is opposed to a reduction in cellular metabolism, assessed through the AlamarBlue reduction and DNA content by the PicoGreen assay, respectively. The data indicated that the electrical field applied can influence the activation of biological signal transduction responsible for cell proliferation and differentiation, which was enhanced by the intrinsic conductivity of the copolymers.

\section{AUTHOR CONTRIBUTIONS}

R.A.d.S. conceived and designed the experiments and wrote the manuscript with input from all co-authors. R.A.d.S. performed the synthesis and characterization of the copolymers. R.X. performed the modeling experiments. S.C. and S.I.C.d.T. discussed all experiments and initiated and led the project.

\section{ACKNOWLEDGMENTS}

The authors thank São Paulo Research Foundation FAPESP (Proc. Nos. 2015/26308-7, 2017/08349-3, and 2018/18846-7) and Engineering and Physical Sciences Research Council (Grant No. $\mathrm{EP} / \mathrm{I02249X/1)}$ for the financial support and grant funding, respectively. In addition, the authors of this article agree to make the data of the results obtained available when solicited.

\section{DATA AVAILABILITY}

The data that support the findings of this study are available within the article and its supplementary material.

\section{REFERENCES}

${ }^{\mathbf{1}}$ R. Hernández, C. Jiménez-Luna, J. Perales-Adán, G. Perazzoli, C. Melguizo, and J. Prados, Biomol. Ther. (Seoul) 28, 34 (2020).

2J. R. Pepper, M. A. Herbert, J. R. Anderson, and W. P. Bobechko, J. Orthop. Res. 14, 296 (1996).

${ }^{3}$ C. Q. Huang, R. K. Shepherd, P. M. Seligman, and G. M. Clark, Hear. Res. 116, 55 (1998).

${ }^{\mathbf{4}}$ M. Griffin, A. Sebastian, J. Colthurst, and A. Bayat, PLoS ONE 8, e72978 (2013).

${ }^{5}$ R. Balint, N. J. Cassidy, and S. H. Cartmell, Acta Biomater. 10, 2341 (2014).

${ }^{6}$ R. B. Martin, J. Biomech. 12, 55 (1979).

${ }^{7}$ C. Ribeiro, D. M. Correia, I. Rodrigues, L. Guardão, S. Guimarães, R. Soares, and S. Lanceros-Méndez, Mater. Lett. 209, 118 (2017).

${ }^{8}$ R. Balint, N. J. Cassidy, L. Araida Hidalgo-Bastida, and S. Cartmell, J. Biomater. Tissue Eng. 3, 212 (2013).

${ }^{9}$ A. Rupani, R. Balint, and S. H. Cartmell, Cell Health Cytoskelet. 4, 49 (2012).

${ }^{10}$ W. Deng et al., Tissue Eng. 11, 110 (2005).

${ }^{11}$ N. P. Lang, T. G. Wilson, and E. F. Corbet, Clin. Oral Implants Res. 11, 146 (2000).

${ }^{12}$ U. Bragger, S. Aeschlimann, W. Burgin, C. H. F. Hammerle, and N. P. Lang, Clin. Oral Implants Res. 12, 26 (2001).

${ }^{13}$ J. R. Sanchez-Ramos, J. Neurosci. Res. 69, 880 (2002).

${ }^{14} \mathrm{~N}$. Li et al., Sci. Rep. 3, 1604 (2013). 
${ }^{15}$ C. Zhao, A. Tan, G. Pastorin, and H. K. Ho, Biotechnol. Adv. 31, 654 (2013).

${ }^{16}$ M. L. Hernández-Bule, C. L. Paíno, M. Á. Trillo, and A. Úbeda, Cell. Physiol. Biochem. 34, 1741 (2014).

${ }^{17}$ R. K. Jaiswal, N. Jaiswal, S. P. Bruder, G. Mbalaviele, D. R. Marshak, and M. F. Pittenger, J. Biol. Chem. 275, 9645 (2000).

${ }^{18}$ T. Dvir, B. P. Timko, D. S. Kohane, and R. Langer, Nat. Nanotechnol. 6, 13 (2011).

${ }^{19}$ S. Stříteský, A. Marková, J. Víteček, E. Šafaříková, M. Hrabal, L. Kubáč, L. Kubala, M. Weiter, and M. Vala, J. Biomed. Mater. Res. Part A 106, 1121 (2018).

${ }^{20}$ D.-I. D. Cho and H. J. Yoo, J. Microelectromech. Syst. 24, 10 (2015).

${ }^{21}$ A. C. da Silva, R. A. da Silva, M. J. P. G. Souza, P. M. Montoya, R. Bentini, T. Augusto, R. M. Torresi, L. H. Catalani, and S. I. Córdoba de Torresi, Biointerphases 15, 021003 (2020).

${ }^{22}$ Y. S. Jeong, W.-K. Oh, S. Kim, and J. Jang, Biomaterials 32, 7217 (2011).

${ }^{23}$ J. G. Hardy, J. Y. Lee, and C. E. Schmidt, Curr. Opin. Biotechnol. 24, 847 (2013).

${ }^{24}$ A. C. da Silva, M. J. Higgins, and S. I. Córdoba de Torresi, Mater. Sci. Eng. C 99, 468 (2019).

${ }^{25}$ A. C. Da Silva, A. T. S. Semeano, A. H. B. Dourado, H. Ulrich, and S. I. Cordoba De Torresi, ACS Omega 3, 5593 (2018).

${ }^{26}$ R. Balint, N. J. Cassidy, and S. H. Cartmell, Tissue Eng. Part B Rev. 19, 48 (2013).

${ }^{27}$ L. Pan et al., Proc. Natl. Acad. Sci. U.S.A. 109, 9287 (2012).

${ }^{28}$ B. P. Yu, Physiol. Rev. 74, 139 (1994).

${ }^{29}$ A. C. da Silva and S. I. Córdoba de Torresi, Front. Mater. 6, 98 (2019).

${ }^{30}$ C. A. Gregory, W. Grady Gunn, A. Peister, and D. J. Prockop, Anal. Biochem. 329, 77 (2004).

${ }^{31}$ A. Wilkinson, R. N. Hewitt, L. E. McNamara, D. McCloy, R. M. Dominic Meek, and M. J. Dalby, Acta Biomater. 7, 2919 (2011).

${ }^{32}$ W.-S. Yeow, A. Baras, A. Chua, D. M. Nguyen, S. S. Sehgal, D. S. Schrump, and D. M. Nguyen, J. Thorac. Cardiovasc. Surg. 132, 1356 (2006).

${ }^{33}$ D. Fischer, Y. Li, B. Ahlemeyer, J. Krieglstein, and T. Kissel, Biomaterials 24, 1121 (2003).

${ }^{34}$ E. J. Pavlik et al., Cancer Invest. 3, 413 (1985).

${ }^{35}$ L. Khatib, D. E. Golan, and M. Cho, FASEB J. 18, 1903 (2004).

${ }^{36}$ L. Leppik, K. M. C. Oliveira, M. B. Bhavsar, and J. H. Barker, Eur. J. Trauma Emerg. Surg. 46, 231 (2020).

${ }^{37}$ M. R. Cho, IEEE Trans. Plasma Sci. 30, 1504 (2002).

${ }^{38}$ P. W. Brandt and A. R. Freeman, Science 155, 582 (1967).

${ }^{39}$ F. Ke et al., Stem Cells 32, 2799 (2014).

${ }^{40}$ D. Liu, C. Yi, C.-C. Fong, Q. Jin, Z. Wang, W.-K. Yu, D. Sun, J. Zhao, and M. Yang, Biol. Med. 10, 1153 (2014).

${ }^{41}$ G. Thrivikraman, S. K. Boda, and B. Basu, Biomaterials 150, 60 (2018).

${ }^{\mathbf{4 2}}$ M.-T. Tsai, W.-J. Li, R. S. Tuan, and W. H. Chang, J. Orthop. Res. 27, 1169 (2009).

${ }^{43}$ W.-W. Hu, Y.-T. Hsu, Y.-C. Cheng, C. Li, R.-C. Ruaan, C.-C. Chien, C.-A. Chung, and C.-W. Tsao, Mater. Sci. Eng. C 37, 28 (2014).

${ }^{44}$ P. Marszalek, D. S. Liu, and T. Y. Tsong, Biophys. J. 58, 1053 (1990).

${ }^{45}$ B. Valic, M. Golzio, M. Pavlin, A. Schatz, C. Faurie, B. Gabriel, J. Teissié, M.-P. Rols, and D. Miklavcic, Eur. Biophys. J. 32, 519 (2003).
${ }^{46}$ D. K.-L. Cheng, L. Tung, and E. A. Sobie, Am. J. Physiol. Circ. Physiol. 277, H351 (1999).

${ }^{47}$ M. Kayahara, X. Wang, and C. Tournier, Mol. Cell. Biol. 25, 3784 (2005).

${ }^{48}$ M. Sasaki, Science 312, 589 (2006).

${ }^{49}$ S. A. Pless, J. D. Galpin, A. P. Niciforovic, and C. A. Ahern, Nat. Chem. Biol. 7, 617 (2011).

${ }^{50}$ H. Yoshimoto, Y. M. Shin, H. Terai, and J. P. Vacanti, Biomaterials. 24, 2077 (2003)

${ }^{\mathbf{5 1}}$ A. Martínez-Ruiz, S. Cadenas, and S. Lamas, Free Radic. Biol. Med. 51, 17 (2011).

52 A. Lacy-hulbert, J. C. Metcalfe, and R. Hesketh, FASEB J. 12, 395 (1998).

${ }^{53}$ G. Chan and D. J. Mooney, Trends Biotechnol. 26, 382 (2008).

${ }^{54}$ K. R. Mahtani, M. Brook, J. L. E. Dean, G. Sully, J. Saklatvala, and A. R. Clark, Mol. Cell. Biol. 21, 6461 (2001).

${ }^{55}$ J. P. Crow and J. S. Beckman, "The importance of superoxide in nitric oxidedependent toxicity," in Biological Reactive Intermediates V. Advances in Experimental Medicine and Biology, edited by Snyder R. (Springer, Boston, MA, 1996), Vol. 387, pp. 147-161, see https://doi.org/10.1007/978-1-4757-9480-9_21

${ }^{56}$ M. C. Ruth, Y. Xu, I. H. Maxwell, N. G. Ahn, D. A. Norris, and Y. G. Shellman, J. Invest. Dermatol. 126, 862 (2006).

${ }^{57}$ M. L. Pall, J. Cell. Mol. Med. 17, 958 (2013).

${ }^{58}$ J. Hammond and J.-L. Balligand, J. Mol. Cell. Cardiol. 52, 330 (2012).

${ }^{59}$ V. Darley-Usmar, H. Wiseman, and B. Halliwell, FEBS Lett. 369, 131 (1995).

${ }^{60} \mathrm{G}$. Ferrer-Sueta and R. Radi, ACS Chem. Biol. 4, 161 (2009).

${ }^{61}$ M. P. Murphy, Biochim. Biophys. Acta Bioenerg. 1411, 401 (1999).

${ }^{62}$ A.-L. Levonen, R. P. Patel, P. Brookes, Y.-M. Go, H. Jo, S. Parthasarathy, P. G. Anderson, and V. M. Darley-Usmar, Antioxid. Redox Signal 3, 215 (2001).

${ }^{63}$ J. P. Bolaños, A. Almeida, V. Stewart, S. Peuchen, J. M. Land, J. B. Clark, and S. J. R. Heales, J. Neurochem. 68, 2227 (2002).

${ }^{64}$ M. G. Salgo, E. Bermudez, G. L. Squadrito, and W. A. Pryor, Arch. Biochem. Biophys. 322, 500 (1995).

${ }^{65}$ S. Burney, J. L. Caulfield, J. C. Niles, J. S. Wishnok, and S. R. Tannenbaum, Mutat. Res. Mol. Mech. Mutagen. 424, 37 (1999).

${ }^{66}$ M. G. Salgo and W. A. Pryor, Arch. Biochem. Biophys. 333, 482 (1996).

${ }^{67}$ M. H. Ryu, H. M. Park, J. Chung, C. H. Lee, and H. R. Park, Biochem. Biophys. Res. Commun. 393, 11 (2010).

${ }^{68}$ M. Simko, Curr. Med. Chem. 14, 1141 (2007).

${ }^{69} \mathrm{M}$. Cappelletti, I. Zampaglione, G. Rizzuto, G. Ciliberto, N. La Monica, and E. Fattori, J. Gene Med. 5, 324 (2003).

${ }^{70}$ A. C. Gadano, P. Sogni, S. Yang, S. Cailmail, R. Moreau, P. Nepveux, D. Couturier, and D. Lebrec, J. Hepatol. 26, 678 (1997).

${ }^{71}$ M. K. Shin, M.-K. Kim, Y.-S. Bae, I. Jo, S.-J. Lee, C.-P. Chung, Y.-J. Park, and D. S. Min, Cell. Signal 20, 613 (2008).

${ }^{72}$ R. Hess, A. Jaeschke, H. Neubert, V. Hintze, S. Moeller, M. Schnabelrauch, H.-P. Wiesmann, D. A. Hart, and D. Scharnweber, Biomaterials 33, 8975 (2012).

${ }^{73}$ See supplementary material at https://www.scitation.org/doi/suppl/10.1116/ 6.0001435 for a scheme of the biorector and a computational modelling of the electric field distribution inside it. 